Notfall Rettungsmed 2021 24 (Suppl 1):S45 https://doi.org/10.1007/s10049-021-00918-5 Published online: 27 July 2021

(c) The Author(s) 2021

\section{Erratum to: Which health-related reasons lead to prehospital emergency care and how does subjective emergency status connect to subsequent care? Emergency medical service patients' survey linked to health claims data}

\author{
Silke Piedmont ${ }^{1} \cdot$ Anna Katharina Reinhold ${ }^{2,3} \cdot$ Jens-Oliver Bock ${ }^{4} \cdot$ Enno Swart $^{1}$. \\ Bernt-Peter Robra' \\ 'Institute of Social Medicine and Health Systems Research, University Magdeburg, Magdeburg, Germany \\ ${ }^{2}$ Clinic of Trauma Surgery, University Magdeburg, Magdeburg, Germany \\ ${ }^{3}$ Department for Health Services Research, Faculty of Medicine and Health Sciences, Carl von \\ OssietzkyUniversity Oldenburg, Oldenburg, Germany \\ ${ }^{4}$ BKK Dachverband e.V., Berlin, Germany
}

\section{Erratum to:}

Notfall Rettungsmed 2020

https://doi.org/10.1007/s10049-020-

00832-2

The authors point out that in the methods section of the original article, the following sentence has been corrected. Please note the correct sentence:

We conducted descriptive and inferential analysis with IBM $^{\circledR}$ SPSS ${ }^{\circledR}$ Statistics Version 25 (IBM Corporation, Ar-monk, NY, USA) and Microsoft Excel 2016 using pairwise deletion.

\section{Corresponding address}

\section{Silke Piedmont}

Institute of Social Medicine and Health Systems Research, University Magdeburg

Leipziger Str. 44, 39120 Magdeburg, Germany silke.piedmont@mhb-fontane.de
Funding. This work was supported by the German Innovation Fund of the Joint Federal Committee (G-BA) [grant number 01VSF17032].
Funding. Open Access funding enabled and organized by Projekt DEAL.

Open Access. This article is licensed under a Creative Commons Attribution 4.0 International License, which permits use, sharing, adaptation, distribution and reproduction in any medium or format, as long as you give appropriate credit to the original author(s) and the source, provide a link to the Creative Commons licence, and indicate if changes were made. The images or other third party material in this article are included in the article's Creative Commons licence, unless indicated otherwise in a credit line to the material. If material is not included in the article's Creative Commons licence and your intended use is not permitted by statutory regulation or exceeds the permitted use, you will need to obtain permission directly from the copyright holder. To view a copy of this licence, visit http://creativecommons.org/licenses/by/4.0/.

The online version of the original article can be found under https://doi.org/10.1007/s10049020-00832-2. 